\title{
Section 33 and the Relationship Between LEGISLATURES AND COURTS
}

\author{
The Honourable Mr. Justice Michel Bastarache
}

\section{INTRODUCTION}

The introduction of the Constitution Act, $1982^{1}$ was greatly debated. While many of the substantive provisions received considerable attention by various committees and interested organizations, the limitation provisions, sections 1 and 33 were particularly contentious. Today, I would like to discuss the early vision of the new relationship to be forged between the judicial and legislative branches of government. ${ }^{2}$ Sections 1 and 33 were intended to strike an appropriate balance between law-maker and law-reviewer. Each safeguarded abuse by the other. Throughout the drafting period, however, many expressed concern about shifting Canada's political system from a parliamentary supremacy to a constitutional one. Specifically, how each would respond to their new roles in light of sections 1 and 33. To determine whether these concerns have materialized, I will compare these suspicions with the actual relationship that has evolved between the courts and legislatures since the entrenchment of the Constitution Act, 1982.

In comparing and contrasting the intention of the framers ${ }^{3}$ with my view of the balance of power struck between the government and the court, I do not endorse an originalist interpretation of sections 1 or 33. As you are undoubtedly aware, the Supreme Court of Canada adopted a "living tree"

Constitution Act, 1982, being Schedule B to the Canada Act 1982 (U.K.), 1982, c.11, online: Justice Canada <http://laws. justice.gc.ca/en/const/annex_e.html>.

2 This article is a slightly revised version of a paper delivered at the conference on Legislatures and Consitutionalism: The Role of Legislatures in the Constitutional States, Centre for Constitutional Studies, Banff Centre, Banff, Alberta, 2-5 July 2004 .

I note at the outset that my comments with respect to the framers of the Constitution are restricted to Canadian academics and federal/provincial political actors. approach to the interpretation of the Constitution. ${ }^{4}$ In the Motor Vehicle Reference, the Court gave very little weight to evidence of the framers' intention as a tool of constitutional interpretation. ${ }^{5}$ Thus, the Court endorsed a substantive approach to the principles of fundamental justice rather than a merely procedural interpretation as appeared to be intended by the framers. Therefore, my references to "original intent" are solely for tracing the development of sections 1 and 33. The idea of a limitation clause was first included in 1968 in Pierre Elliott Trudeau's proposal for a Canadian Charter of Human Rights. At the time, the limitation of rights was contemplated in times of emergency only. ${ }^{6}$ By the time a draft of the Charter of Rights and Freedoms was presented in the House of Commons in October 1980, ${ }^{7}$ a more fulsome limitation clause was included. ${ }^{8}$ Based in part on the European Convention of Human Rights and Fundamental Freedoms, it guaranteed

See e.g., Edwards v. Canada (Attorney General), (1929) [1930] A.C. 124 at 136 (P.C.); Law Society of Upper Canadav. Skapinker, [1984] 1 S.C.R. 357 at 365, online: LexUM <http://www.lexum.umontreal.ca/csc-scc/en/pub/1984/vol1/ html/1984scr1_0357.html>; Hunter v. Southam Inc., [1984] 2 S.C.R. 145 at 155-56, online: LexUM <http://www.lexum. umontreal.ca/c s c-scc/en/pub/1984/vol2/h tm 1/ $1984 \mathrm{scr} 2$ 0145.html $>$; and Reference Re Section 94(2) of the Motor Vehicle Act, R.S.B.C 1979, [1985] 2 S.C.R. 486, online: CanLII <http://www.canlii.org/ca/cas/scc/1985/1985 scc72. html $>$ [Motor Vehicle Reference]. For a discussion of the rejection of the original intent doctrine in Canada see Justice Ian Binnie, "Constitutional Interpretation and Original Intent" (2004) 23 Supreme Court Law Review (2d) 345.

Motor Vehicle Reference, ibid. at 508.

6 Canada, Department of Justice, A Canadian Charter of Human Rights (Ottawa: Queen's Printer, 1968) at 30.

House of Commons Debates (6 October 1980) at 3274 (Rt. Hon. P.E. Trudeau).

8 The provision was first introduced and adopted in principle at the third federal-provincial Constitutional Conference in February 1971. Dale Gibson, "Reasonable Limits Under the Canadian Charter of Rights and Freedoms" (1985) 15 Manitoba Law Journal 27. 
the rights and freedoms set out in the Charter ${ }^{9}$ subject only to such reasonable limits as generally accepted in a free and democratic society with a parliamentary system of government. The limitation clause was said to be unique for two reasons. It explicitly limited rights, unlike the American Bill of Rights, and it appeared to apply to all Charter rights, unlike the European Convention.

The challenge of the limitation clause was to create a provision that provided constitutional protection of rights and freedoms while preserving some degree of parliamentary control. Concerns about majoritarianism led to three changes by the Joint Parliamentary Committee ${ }^{10}$ First, the phrase "prescribed by law" was included. Second, the words "with a parliamentary system of government" were removed. Third, the phrase "as are generally accepted" was removed and replaced with the words "as can be demonstrably justified." It is opined that these changes unequivocally placed the onus on the government to justify any limitation on rights and set a more rigorous standard for justification. ${ }^{11}$ Those who were reluctant to completely abolish the doctrine of parliamentary sovereignty and who were concerned with an unpredictable use of judicial power insisted on a greater role for the legislature. Out of the impasse that resulted, section 33 was created.

All agreed that section 33 was intended to give the legislature the so-called "last word." The controversy centred on the extent to which the provision would be used. It appeared that section 33 was intended as a tool to correct "judicial errors." ${ }^{12}$ This is obvious from the federal Minister

Canadian Charter of Rights and Freedoms, Part I of the Constitution Act, 1982, being Schedule B to the Canada Act 1982 (U.K.), 1982, c. 11, online: CanLII http://www.canlii.org/ ca/const_en/const1982.html\#I> [Charter].

10 Timothy J. Christian, "The Limitation of Liberty: A Consideration of Section 1 of the Charter of Rights and Freedoms" (1982) University of British Columbia Law Review 105 at $113-15$.

11 Christian, ibid. at 107; Anne F. Bayefsky, "The Judicial Function under the Canadian Charter of Rights and Freedoms" (1987) 32 McGill Law Journal 791 at 811.

12 See Paul C. Weiler, "Of Judges and Rights, or Should Canada Have a Constitutional Bill of Rights?” (1980) 60 Dalhousie Review 205. See also Donna Greschner \& Ken Norman, "The Courts and Section 33" (1987) 12 Queen's Law Journal 155 at 189 , according to which "Two key political participants from the provinces have also expressed opinions, albeit after passage of the Charter, that s. 33 was a remedy for court decisions" of Justice's description of section 33 as a "safety valve" ${ }^{13}$ and from the following statement made by Chief Justice Roy McMurtry, then Attorney General of Ontario:

The fact is that the clause does provide a form of balancing mechanism between the legislators and the courts in the unlikely event of a decision of the courts that is clearly contrary to the public interest. ${ }^{14}$

Further, provinces contemplated the use of the notwithstanding clause only in the face of strong public support. ${ }^{15}$ As a result, many framers argued that the notwithstanding clause would be rarely used and that it would only be applied to noncontroversial issues. ${ }^{16}$ The provincial legislatures felt that it was essential to prevent a possible misuse of this new constitutional document by the courts.

It was apparent that sections 1 and 33 would create a new form of parliamentary sovereignty. The shape of this relationship would only be known once the courts and the legislature had settled into their new roles. Nevertheless, academic speculation about the future of these sections abounded.

The future application of section 1 by the courts raised several questions such as: Would section 1 apply only after a prima facie violation of a guaranteed right or freedom? How would this external limit apply to provisions that were internally limited? What is a "reasonable limit"? What type of evidence could be adduced to demonstrate the justification? and most importantly, what degree of scrutiny would the

[footnote omitted].

13 House of Commons Debates, 17 (20 November 1981) at 13042 (Hon. Jean Chrétien).

14 Honourable R. Roy McMurtry, "The Search for a Constitutional Accord - A Personal Memoir" (1982) 8 Queen's Law Journal 28 at 65 .

15 PaulC. Weiler, "The Evolution of the Charter: A View from the Outside" in Joseph M. Weiler \& Robin M. Elliot, eds., Litigating the Values of a Nation: The Canadian Charter of Rights and Freedoms (Toronto: Carswell, 1986) 49 at 57.

16 See David Johansen \& Philip Rosen, "The Notwithstanding Clause of the Charter" (Revised September 1997), online: Library of Parliament, Parliamentary Information \& Research Service <www .parl.gc.ca/information/library/PRBpubs/bp194e.htm $>$. 
court subject the legislature to ${ }^{17}$ Some questioned whether the Supreme Court of Canada and other courts would afford high deference to the legislature based on its earlier approach to the Canadian Bill of Rights. ${ }^{18}$

For its part, section 33 also generated much commentary at the outset. Academics speculated that the sunset clause reigned in the power of the legislature, as it would force "periodic reconsideration of each exercise of the override power, at intervals which (in some jurisdictions at least) will often yield a change of government." 19 As with all exercises of parliamentary power, the political ramifications of such decisions would occur at the ballot box. If the government wished to re-invoke the override, such a decision would again be subject to public debate.

Interestingly, there was also some speculation on the applicability of section 1 to section 33 . Professor Brian Slattery predicted that legislation fortified by the override would continue to fall within the reasonable limits required under section 1. In his view, courts would have to decide "whether it is reasonable and demonstrably justified in the circumstances that the statute should be exempted from judicial review for noncompliance with the relevant Charter provision." 20

To date, no court has addressed the application of section 1 to section 33 . Nevertheless, the use of section 33 by legislatures reveals some unexpected developments.

The only thing that was accurately predicted was the infrequent use of section 33. In the twenty-two years since the Charter's entrenchment, the notwithstanding clause has been used seventeen times by the Québec, Alberta,

17 William E. Conklin, "Interpreting and Applying the Limitations Clause: An Analysis of Section 1" (1982) 4 Supreme Court Law Review 75; Christian, supra note 10; and Gibson, supra note 8 .

18 Conklin, ibid. at 79.

19 Peter W. Hogg, "A Comparison of the Canadian Charter of Rights and Freedoms with the Canadian Bill of Rights" in Walter S. Tarnopolsky \& Gérald A. Beaudoin, eds., The Canadian Charter of Rights and Freedoms: Commentary (Toronto: Carswell, 1982) 1 at 11.

20 Brian Slattery, "Canadian Charter of Rights and Freedoms Override Clause Under S. 33 - Whether Subject to Judicial Review Under Section 1" (1983) 61 Canadian Bar Review 391 at 393 [emphasis in original].
Saskatchewan, and Yukon legislatures. ${ }^{21}$ The most notorious uses include the omnibus invocation of section 33 by the National Assembly in 1982, the adoption of Bill 178 by the National Assembly following the Supreme Court of Canada's decision in Ford ${ }^{22}$ and Devine, ${ }^{23}$ and the pre-emptive use by Saskatchewan in its back-to-work legislation. These were subject to much public debate, but the reaction was not sufficiently negative to force government to reconsider the use of section 33 . Public pressure did, however, result in the Alberta legislature's withdrawal of Bill 26, the controversial legislation precluding compensation for victims of sexual sterilization.

One could not have anticipated that thirteen of the seventeen uses would go virtually unnoticed by the public. This was certainly the case when Alberta used the clause to protect the traditional definition of marriage in $2000 .{ }^{24}$ It is opined that the lack of public debate has resulted from the invocation of section 33 at the time of enactment of the impugned provisions. This pre-emptive use shelters the provisions from judicial review, an application starkly different from the errorcorrecting function that was originally intended. ${ }^{25}$ Indeed, the notwithstanding clause has rarely been used as intended - to remedy court decisions that run contrary to popular opinion. This is especially surprising when one considers that the Supreme Court of Canada has made difficult social and political decisions to protect minorities in Canada.

Section 1 , on the other hand, initially appeared to be the definitive standard in Canadian constitutional jurisprudence. In its first applications of section 1, the Supreme Court of

21 Tsvi Kahana, "The Notwithstanding Mechanism and Public Discussion: Lessons From the Ignored Practice of Section 33 of the Charter" (2001) 44:3 Canadian Public Administration 255.

22 Ford v. Quebec (Attorney General), [1988] 2 S.C.R.712, online: LexUM <http://www.lexum.umontreal.ca/csc-scc/en/ pub/1988/vol2/html/1988scr2_0712.html>.

${ }^{23}$ Devine v. Quebec (Attorney General), [1988] 2 S.C.R. 790, online: LexUM <http://www.lexum.umontreal.ca/csc-scc/en/ pub/1988/vol2/html/1988scr2_0790.html>.

24 While certain newspapers reported the event in the days following the enactment of the bill, this did not provoke any public debate or discussion on the matter. Kahana, supra note 19 at 269 .

25 See How ard Leeson, "Section 33, The Notwithstanding Clause: A Paper Tiger?" (2000) 6:4 Choices 3 at 15: "Interestingly, many who had agreed with the insertion of a nonobstante clause in 1981 had not anticipated that it would be used to 'bullet-proof' legislation." See also Kahana, ibid. at 277. 
Canada separated the infringement and justification analyses and eventually established a formalistic approach to the latter in R. v. Oakes. ${ }^{26}$ This had two effects. First, it affirmed a universal application of section 1 where there was a prima facie infringement of a protected right or freedom. Second, it confirmed that the onus rested on the government to justify its infringement and that the threshold for justification was high.

As the jurisprudence has grown, the Oakes test has evolved. The minimal impairment requirement was softened; the final proportionality test was nuanced. Two changes, in particular, have attracted much academic commentary: first, an alleged shift towards a categorical approach to section 1 and, second, the apparent softening of the justification threshold.

As the Supreme Court of Canada defined substantive rights, it became apparent that section 1 would apply differently to those rights that were internally limited. For example, the Court has never found that an unreasonable search or seizure could be justified as a reasonable limit. ${ }^{27} \mathrm{Hogg}$ opines that the right to be free from cruel and unusual punishment would fail the justification analysis. Likewise, apart from a few dissenting opinions, the Court has never upheld a section 7 violation under section $1 .{ }^{28}$ Although each of these provisions are subject to the Oakes framework, academics argue that section 1 has no real work to do vis-à-vis these qualified rights. As a result, a categorical approach has developed. The Court has recently clarified that the balancing of individual and societal interests within section 7 is relevant only when elucidating a particular principle of fundamental justice. ${ }^{29}$ This may

26 [1986] 1 S.C.R. 103. The formalism of the Oakes test was both praised (Peter W. Hogg \& Roland Penner, "The Contribution of Chief Justice Dickson to an Interpretive Framework and Value System for Section 1 of the Charter of Rights" (1991) 20 Manitoba Law Journal 428 at 429) and criticized (Pierre Blache, "The Criteria of Justification Under Oakes: Too Much Severity Generated Through Formalism" (1991) 20 Manitoba Law Journal 437).

27 Peter W.Hogg, Constitutional Law of Canada, $4^{\text {th }}$ ed., looseleaf (Scarborough: Carswell, 1997) at 35-43 [Hogg, Constitutional Law].

28 The same has been said of ss. 11 and 12. Hogg opines that the latter could never be saved under s. 1. Hogg, Constitutional Law, ibid. at 33-45.

$29 \quad$ R. v. Malmo-Levine, R. v. Caine, [2003] 3 S.C.R. 571 at para. 98, 2003 SCC 74, online: CanLII <http://www.canlii.org/ca/ cas/scc/2003/2003 scc 74.html>. increase the role of section 1 , thereby shifting the jurisprudence closer to a universal approach.

The second development concerns the increasing contextualization of the justification analysis. The Court in Irwin Toy Ltd. v. Quebec (Attorney General) affirmed the importance of context. The Court recognized that a different approach to section 1 was warranted where the impugned legislation was intended to balance the interests of different groups as opposed to where the legislature acts as the singular antagonist of the individual. $^{30}$ The contextual analysis was expanded upon in Thomson Newspapers $v$. Canada (Attorney General), where the Court held that context is the indispensable handmaiden to the proper characterization of the objective of the impugned provision, to determining whether that objective is justified, and to weighing whether the means used are sufficiently closely related to the valid objective so as to justify an infringement of a Charter right. ${ }^{31}$

The Court went on to set out the following contextual factors: (1) nature of the harm and the inability to measure it, (2) the vulnerability of the group the legislature is trying to protect, (3) that group's own subjective fears and apprehension of harm, (4) the inability to measure scientifically a particular harm in question or the efficaciousness of a remedy, and (5) the enhancement of other Charter values.

Several academics have commented on the effect of the contextual analysis on the development of section 1 . These claims include increasing subjectivity, which results in unpredictability, decreasing evidentiary requirements, and the further categorization of the section 1 analysis. $^{32}$

30 [1989] 1 S.C.R. 927 at 993-94 [Irwin Toy], online: CanLII $<$ http://www.canlii.org/ca/cas/scc/1989/1989scc37.html $>$.

31 [1998] 1 S.C.R. 877 at para. 87, online: CanLII <http://www. canlii.org/ca/cas/scc/1998/1998scc43.html>

32 Christopher D. Bredt \& Adam M. Dodek, "The Increasing Irrelevance of Section 1 of the Charter" (2001) 14 Supreme Court Law Review (2d) 175; Christopher M. Dassios \& Clifton P. Prophet, "Charter Section 1: The Decline of Grand Unified Theory and the Trend Towards Deference in the Supreme Court of Canada" (1993) 15 Advocates Quarterly 299; Jamie Cameron, "The Original Conception of Section 1 and Its Demise: A Comment on Irwin Toy Ltd. v. Attorney General of Quebec" (1989) 35 McGill Law Journal 253. 
In my view, the contextual analysis represents an inevitable growth from the original Oakes framework, which was said to be objective but formalistic. Indeed, the contextual factors ensure that the Court is sensitive to the competing rights and values that exist in Canadian society when determining the constitutionality of legislation. This analysis also respects the different institutional competencies of the Court and the legislature and requires that the former exercise an appropriate degree of deference.

As I noted at the outset, many of the drafters' expectations, and the academic speculation on this new constitutional relationship, did not bear fruit. This is, in part, the result of the Court's early rejection of original intent as an approach to interpreting the Charter. Thus, section 1 will continue to evolve as the relationship matures. It cannot, however, be said that the respective roles of the legislature and court are completely unexpected. This was noted on the twentieth anniversary of the Charter, when Senator Michael Kirby, who was head of Mr. Trudeau's federalprovincial relations office in 1982, stated:

The notion that the Supreme Court has taken an activist position that nobody anticipated is not true. It was one of the most hotly debated items at the time we did the Charter.... All the court has done is to use the power they were very consciously given at the time by the politicians of the day. ${ }^{33}$

To conclude, when tracing the evolution of sections 1 and 33, it is apparent that the perception of their relative importance has changed since the inception of the Charter because of the practical application of each.

The Honourable Mr. Justice

Michel Bastarache

Supreme Court of Canada

33 Luiza Chwialkowska, "Maybe They Went a Bit Far" National Post (17 April 2002) A 1 at A 12 . 